\title{
INDONESIAN AUTHORS WRITING THEIR DISCUSSION SECTIONS BOTH IN ENGLISH AND INDONESIAN RESEARCH ARTICLES
}

\author{
Lulus Irawati ${ }^{1}$, Ali Saukah ${ }^{2}$, and Suharmanto ${ }^{3}$ \\ ${ }^{1)}$ Universitas PGRI Madiun, ${ }^{2,3)}$ Universitas Negeri Malang \\ e-mail: 1)lulusirawati@gmail.com ${ }^{2}$ alisaukah@yahoo.com ${ }^{3)}$ suharmanto.fs@um.ac.id
}

\begin{abstract}
The study aims to investigate how Indonesian authors write their English and Indonesian research article (RA) discussion sections. There were 7 Indonesian authors who write 1 English research article and 1 Indonesian research article published in national accredited journals. The study executed rhetorical moves designed by Swales (1990) to be used here as the instrument. In general, the findings show that 7 Indonesian authors operate not too different rhetorical patterns of English and Indonesian RA discussion sections viewed from moves occurrences, completeness, and order of the move structures. Nearly all 7 Indonesian authors show 5 moves in the English RA discussion section consisting of statement of the results-(un)expected outcome-reference to previous research-explanation-deduction and hypothesis. They use 6 moves in the Indonesian RA discussion section consisting of statement of the results-(un)expected outcome-reference to previous research-explanation-exemplification-deduction and hypothesis. However, each author has his/her specific move structure seen from the moves order and moves frequency. The specific uses of move structure are explained with examples in the forms of sentences or phrases. Thus, the authors are in the position of having their rhetorical patterns suited the context and communities.
\end{abstract}

Keywords: Indonesian authors, research articles (RA), discussion sections, rhetorical patterns

\section{PILIHAN POLA RETORIKA PENULIS INDONESIA DALAM MENULIS BAGIAN PEMBAHASAN ARTIKEL PENELITIAN BERBAHASA INGGRIS DAN BERBAHASA INDONESIA}

\begin{abstract}
Abstrak: Penelitian ini bertujuan untuk meneliti bagaimana penulis Indonesia menulis bagian pembahasan artikel penelitian berbahasa Inggris dan berbahasa Indonesia. Data diperoleh dari 7 penulis Indonesia yang pernah menulis dan mempublikasi 1 artikel penelitian berbahasa Inggris dan 1 artikel penelitian berbahasa Indonesia di jurnal ilmiah terakreditasi nasional. Penelitian ini menggunakan pola retorika (moves) yang dikembangkan oleh Swales (1990) sebagai instrumen untuk menganalisis bagian pembahasan artikel penelitian. Secara umum, hasil penelitian menunjukkan bahwa ketujuh penulis Indonesia memilih pola retorika yang tidak terlalu berbeda pada bagian pembahasan yang berbahasa Inggris dan berbahasa Indonesia, dilihat dari frekuensi kemunculan moves, kelengkapan moves, dan urutan movesnya. Sebagian besar penulis memilih 5 moves pada bagian pembahasan yang berbahasa Inggris, yaitu statement of the results-(un)expected outcome-reference to previous researchexplanation-deduction and hypothesis. Bagian pembahasan yang berbahasa Indonesia memiliki 6 moves, yaitu statement of the results-(un)expected outcome-reference to previous research-explanationexemplification-deduction and hypothesis. Walaupun begitu, setiap penulis memiliki pilihan moves tertentu dari segi urutan moves dan frekuensi kemunculannya. Dapat disimpulkan bahwa penulis-penulis Indonesia tersebut memilih pola retorikanya disesuaikan dengan konteks dan komunitas pembaca artikel penelitian di jurnal ilmiah yang mereka pilih.
\end{abstract}

Kata Kunci: Penulis Indonesia, artikel penelitian (RA), bagian pembahasan, pola retorika

\section{INTRODUCTION}

During last decade, there are many studies to examine the people's writing seen from particular patterns that are popularly called genre (for example Kaplan, 1966; Swales, 1990; Mirahayuni, 2002; Susilo, 2004; Kuntjara, 2004; Basthomi, 2006; Tseng, 2011; Ozmen, 2016). Accordingly, the present study is investigating 
how Indonesian authors write discussion sections, both in English and Indonesian research articles. Both English and Indonesian discussion sections of research articles are written by the same Indonesian authors. Author's choices of rhetorical pattern in their writing can be consciously or unconsciously chosen during the time; their writing might be influenced by their cultural, geographical, and linguistic backgrounds. Further, it continues to explore and dig deeply some information supporting the existing rhetoric. The discussion sections of research articles are mostly taken from accredited journals that are published in Indonesia.

The study of contrastive rhetoric has been aimed at not only finding the rhetorical patterns but also identifying the problems faced by L2 2 learners. As stated by Connor (1996), the research in L2 acquisition identify problems in the composition encountered by the L2 learners related to the L1's rhetorical strategies. Having seen from its prior study done by Kaplan, 1966 to recent time, the contrastive rhetoric developed significantly, in terms of focusing the subject of the study. Further, the contrastive rhetoric studies, then, are classified in four domains of investigation: (1) contrastive text linguistic studies; (2) studies of writing as cultural and educational activity; (3) classroom-based contrastive studies; (4) genre-specific investigation (Connor, 2002). The studies reviewed in accordance with the above classification are purposefully chosen in terms of recent publication and investigation.

Various studies came up to fill the gaps of contrastive rhetoric area in terms of investigating different product of writing or text types (genrespecific investigation), changing the subject of the study into the professional writers such as article writers of local and international journals, post-graduate students and many more. Firstly, Susilo (1999) reported the Indonesian writers who write their articles in The Jakarta Post tend to formulate their thesis statement in four ways: inductive pattern, deductive pattern, mid-position and unclearly stated thesis statement. Again, Susilo (2004) investigated thought patterns as reflected in the linguistic features of either English or Indonesian letters written by Indonesians and he found that rhetorical organization developed and organized in Indonesian and English letters were similar in three ways: completely tripartitestructure-constructions, two-element-tripartite structure constructions, and one-elementtripartite structure constructions. Whereas, Chakorn (2002) reported that native speakers may also employ distinctive writing patterns in letters revealing diversity in some rhetorical moves, linguistic realizations, rhetorical appeals and politeness strategies. Further, the area of rhetoric studies have gradually shifted from classroom-based investigating the students' academic writing with specific modes of writing, to genre-specific investigating letters and news articles, which are more contextual ones.

Some studies in rhetoric and genre analysis come up in the surface to flourish the variances. In relation to the RA investigation, there are three popular sections studied, namely abstract, introduction, and discussion. RA introduction and discussion are two challenging sections since both of them require writers to organize their thoughts and ideas comparing with others. These two sections of RA however, are considered problematic. Although some journals provide specific requirement of publishing RA, the ones thought patterns cannot be controlled and may be different from one another. Introduction sections are placed in the beginning to deliver researcher's ideas, beliefs, reasons and reviewing the previous studies in the form of background of the study. Thus, most introduction sections start by stating the general information to the specific one.

On the contrary, discussion section usually starts recapitulating the results, which are the specific ones, next organizing into the general information one. Therefore, it is extremely necessary to conduct more detail investigation that it is in the (contrastive) rhetoric field and not many investigations on the rhetoric of discussion sections are conducted. In Indonesian context, Mirahayuni (2002) investigated generic structure of English Research Articles focusing on Introduction and Discussion sections written by English (Native) and Indonesian (Non Native) writers, which may contribute to their acceptance for international publication. Another idea was done by Al-Qathani (2006) that compared the rhetoric patterns of English and Arabian RA Introduction by inserting educational background as another variable. Purposefully, Basthomi (2006) and Safnil (2013) investigated the rhetoric of English RA Introductions taking from accredited Indonesian journals that obviously written by Indonesian writers and 
looked for the reasons behind the existing of the rhetoric. In terms of rhetoric analysis, Swales' IMRD structure and CARS model (1990) were still relevant to be utilized by these previous researchers.

In accordance with previous studies, the interesting part comes up that investigating English and Indonesian RA discussion sections written by different authors certainly shows the differences and similarities of rhetorical patterns of RA discussion sections, because of some reasons namely; every author has different backgrounds such as educational and linguistic backgrounds, she/he is from different country; native or non-native, and she/he may use the writing style required by the selected journals. Having investigated deeper on the rhetorical patterns, we investigate how Indonesian authors write their English and Indonesian RA discussion sections in an attempt to describe the differences and similarities of rhetorical patterns of RA discussion sections. The differences and similarities found can be as a result of the way the authors using the language, since they write using different languages and having particular patterns.

\section{METHODS}

The study was conducted by utilizing content analysis in the area part of qualitative research, since we investigated the rhetorical patterns of English and Indonesian RA discussion sections written by the same Indonesian authors. The source of data consisted of 7 Indonesian authors who have published 1 English RA and 1 Indonesian RA in Indonesian journals. Some reasonable criteria of selecting research articles published in the Indonesian journals were namely (1) The articles were written in English and Indonesian by the same Indonesian authors individually, not in team; (2) The articles were published in Indonesian journals, accredited by DirectorateGeneral ofHigherEducation(DIKTI), as one of indications of qualified and consistent journals; (3) The articles were published in the field of Language and Language Teaching, in which we earned our formal educations;

The data were collected by documenting English and Indonesian RA discussion sections. We focused on Indonesian authors who wrote both English and Indonesian RAs. After getting the relevant data, we classified RA discussion sections on whether it was put as an independent section or combined with the result or finding sections. The RA discussion sections that were put as an independent section could directly be analyzed in the parts of rhetorical pattern or move. Meanwhile, the combined RA discussion was identified by the paragraph that began with the expression 'Based on the result above...'

We analyzed English and Indonesian RA discussions sections as written texts based on their moves. CARS (Create a Space for Research) model developed by Swales (1990) was executed as the instrument. It consisted of 8 moves: Move I (background information), Move II (statement of the results), Move III ((un)expected outcome), Move IV (reference to previous research), Move V (explanation), Move VI (exemplification), Move VII (deduction and hypothesis), and Move VIII (recommendation). We, then continued to display and interprete the data, for the purpose of describing the data naturally. In an effort to know what moves of the paragraphs belong, both data of English and Indonesian RA discussion sections were analyzed a sentence by a sentence. Each move may occur or be repeated many times. It was also possible that some moves did not occur at all. The arrangement of the moves both in English and Indonesian RA discussion sections was not always put orderly. Thus, we tried to find not only the order position and occurrence of the moves, but also the availability or completeness of the moves.

\section{FINDINGS AND DISCUSSION Findings}

After having analyzed the RA discussion sections written by the same authors, 7 Indonesian authors operate not too different rhetorical patterns of English and Indonesian RA discussion sections viewed from moves occurrences, completeness, and order of the move structures. Nearly all 7 Indonesian authors show 5 moves in the English RA discussion section and 6 moves in the Indonesian RA discussion section. The moves found are Move II (statement of the results)-Move III ((un)expected outcome)-Move IV (reference to previous research)-Move V (explanation)-Move VI (exemplification)-Move VII (deduction and hypothesis). Besides the moves aforementioned before, there is one move existing only in the 
Indonesia RA discussion section, namely move VI (exemplification). Move I (background Information) and move VIII (recommendation) are considered absent in both English and Indonesian RA discussion sections, since the moves occur at very small number or do not occur at all. Thus, the recapitulation of moves occurrences of both English and Indonesian RA discussion sections written by Indonesian authors is in Table 1.

The recapitulation of move occurrences informs the occurrence or availability of moves in the discussion sections of English and Indonesian RAs. It also provides information about the move structures, the number of occurrences of each move, and the total number of occurrences of each move. The detail explanation of the move structure, move occurrences and the number of move occurrences is elaborated in the following.

\section{The Rhetorical Patterns of English RA Discussion Sections}

There are 7 discussion sections of English RAs written by Indonesian authors who experienced in the field of language and language teaching. As shown in table 1 above, the occurrence or the availability of moves in the English discussion sections results from the move structures. Each occurrence of the move represents the existence sentences inside the discussion sections. When one move occurs repeatedly two or more, it means that there are also two or more sentences identified as the move.

In short, not all moves occur in the discussion sections of English RA written by Indonesian authors. Based on the data reported above, move I (Background information) and move VIII (recommendation) are rarely found in the discussion sections. The totals of occurrences of both move I and move VIII are only 3 times. It means that there are only 3 out of 7 discussion sections of English RAs having those moves.

However, the occurrences are not always found in the same discussion sections. One discussion section can only have move I (background information) or move VIII (recommendation) and it happens also to other moves. The most frequent moves among 7 discussion sections are move $\mathrm{V}$ (explanation) and move II (statement of results) occurring at 43 times and 37 times respectively. Further, the totals occurrences of the rest moves: move III ((un) expected outcome), move IV (reference to previous research), move VI (exemplification), and move VII (deduction and hypothesis) are $14,22,9$, and 19 times respectively, as shown in table 1 .

Table 1. The Recapitulation of Moves Occurrences of Both English and Indonesian RA Discussion Sections Written by Indonesian Authors

\begin{tabular}{|c|c|c|c|c|c|c|c|c|c|c|}
\hline \multirow[b]{2}{*}{ No. } & \multirow[b]{2}{*}{ Authors } & \multicolumn{8}{|c|}{ Moves Frequency of English Discussion Sections } & \multirow[b]{2}{*}{ Remark } \\
\hline & & $\begin{array}{c}\text { Move } \\
\text { I }\end{array}$ & $\begin{array}{l}\text { Move } \\
\text { II }\end{array}$ & $\begin{array}{c}\text { Move } \\
\text { III }\end{array}$ & $\begin{array}{l}\text { Move } \\
\text { IV }\end{array}$ & $\begin{array}{c}\text { Move } \\
\text { V }\end{array}$ & $\begin{array}{c}\text { Move } \\
\text { VI }\end{array}$ & $\begin{array}{c}\text { Move } \\
\text { VII }\end{array}$ & $\begin{array}{l}\text { Move } \\
\text { VIII }\end{array}$ & \\
\hline 1. & $\mathrm{~A} 1$ & - & 2 & 1 & 4 & 5 & - & 2 & 1 & Two moves are absent \\
\hline 2. & A2 & - & 6 & 4 & 1 & 7 & 3 & 2 & - & Two moves are absent \\
\hline 3. & A3 & 1 & 12 & 3 & 4 & 9 & 6 & 1 & - & One move is absent \\
\hline 4. & A4 & 1 & 1 & - & - & 2 & - & 2 & - & Four moves are absent \\
\hline 5. & A5 & - & 5 & 1 & 4 & 11 & - & 4 & 1 & Two moves are absent \\
\hline 6. & A6 & 1 & 7 & 2 & 5 & 5 & - & 7 & 1 & One move is absent \\
\hline \multirow[t]{2}{*}{7.} & A7 & - & 4 & 2 & 4 & 5 & - & 2 & - & Three moves are absent \\
\hline & Total & 3 & 37 & 14 & 22 & 44 & 9 & 19 & 3 & \\
\hline
\end{tabular}

\begin{tabular}{ccccccccccc}
\hline & & \multicolumn{8}{c}{ Moves Frequency of Indonesian Discussion Sections } & \multirow{2}{*}{ Remark } \\
\cline { 3 - 10 } No. & \multirow{2}{*}{ Authors } & $\begin{array}{c}\text { Move } \\
\text { I }\end{array}$ & $\begin{array}{c}\text { Move } \\
\text { II }\end{array}$ & $\begin{array}{c}\text { Move } \\
\text { III }\end{array}$ & $\begin{array}{c}\text { Move } \\
\text { IV }\end{array}$ & $\begin{array}{c}\text { Move } \\
\text { V }\end{array}$ & $\begin{array}{c}\text { Move } \\
\text { VI }\end{array}$ & $\begin{array}{c}\text { Move } \\
\text { VII }\end{array}$ & $\begin{array}{c}\text { Move } \\
\text { VIII }\end{array}$ & \\
\hline 1. & A1 & - & 4 & 1 & 2 & 4 & 1 & 2 & - & Two moves are absent \\
2. & A2 & - & 1 & - & 1 & 1 & - & - & - & Five moves are absent \\
3. & A3 & - & 5 & 3 & 10 & 9 & 1 & 8 & - & Two moves are absent \\
4. & A4 & - & 9 & 2 & 6 & 13 & 9 & 5 & - & Two moves are absent \\
5. & A5 & - & 3 & 1 & - & 5 & - & 5 & - & Four moves are absent \\
6. & A6 & 1 & 19 & 2 & 12 & 17 & 6 & 4 & - & One move is absent \\
7. & A7 & 2 & 8 & 6 & 3 & 12 & - & 6 & - & Two moves are absent \\
\hline & Total & $\mathbf{3}$ & $\mathbf{4 9}$ & $\mathbf{1 5}$ & $\mathbf{3 4}$ & $\mathbf{6 1}$ & $\mathbf{1 7}$ & $\mathbf{3 0}$ & - & \\
\hline
\end{tabular}


Although, move I (background information) is found in a very small number in the English RA discussion sections, there are some authors operating move I to begin their discussion sections. The move is characterized by the wish of the author recapitulating main points, highlighting theoretical information or reminding the reader of technical information. The phrase "the relevant interview transcript were used to" is recognized as reminding the reader of technical information. The phrase "universal metaphors refer to" is shown that the author wish to highlight theoretical information and the phrase "some important points need to" is indicated as recapitulating main points.

Both move II (statement of results) and move VII (deduction and hypothesis) are used by the 7 Indonesian authors to begin the English RA discussion sections at the field of English Language Teaching (ELT). Move II occurs more in the discussion section of English RAs that simply is recognized from the phrase "the study found" showing to begin the statement of results. The move is seen in the phrase "deserved special attention". It implies that there will be more elaboration of the results in the next sentences or the moves. It is, then, identified as statement of results based on the findings and elaboration in advance. Thus, there are also common words to state the results indeed, such as "found, showed, indicated, and reported".

Move VII (deduction and hypothesis) is found not only to begin, but also to end the English RA discussion sections. The move urges the author to make a claim about the generalizability of all or some of the reported results. In the discussion section of English RA, it is identified from the phrase "another possible hypothesis". The claims are also recognized from the phrases "all findings seem to suggest" and "the findings of the study suggest". The move is then as a reflection of the authors' madeinterpretation based on the results.

The next move occur after move II or move VII is move III ((un)expected outcome). The move contains the author's personal comment based on the reported results, expressing either in positive or negative way. In the discussion section of English RA, it is identified from the sentence "they sometimes found peer response as...". The sentence is recognized as the author expecting outcome occurred based on the results.
At glance, indicating move III is somehow about problematic, since the keywords can be similar to other moves. The best way to confirm is through reading the information that comes before or after it.

Move IV (reference to previous research) and move $\mathrm{V}$ (explanation) are indicated as two most frequent moves in the English RA discussion sections, although the sequence does not always occur respectively. Move V appears repeatedly following the other moves. The move in the discussion sections shows the explanation or elaboration of the previous sentence or move in the sentence "for them it was more convenient to learn the meaning of English words by...". Again, the authors seem to strengthen the previous explanation of reported results.

Meanwhile, move IV (reference to previous research) contains reference for purpose of either comparing with present research or supporting the present research. In the English RA discussion sections, the move is found in the purpose for supporting present research, not comparing with the present research, as indicated from the phrases "this study thus supports the findings of previous researches..." and "in line with this...".

Similar to move I (background information), move VI (exemplification) and move VIII (recommendation) are also considered to be absent in the English RA discussion sections, since move VI is only used by two authors at the small number of move occurrences. Move VI exhibits examples to support an explanation. Some common keywords to represent the move is "for example" or "for instance". Move VIII is also used very rare and about complicated to be recognized in the 7 Indonesian authors' English RA discussion sections. The sentence indicated as move VIII is not directly recommending the further research, but the message implies and suggests the ideas for further research. Thus, understanding the move is extremely based not only on the move itself, but also the previous and the coming moves.

\section{The Rhetorical Patterns of Indonesian RA Discussion Sections}

Similar to discussion sections of English RAs, there are also 7 discussion sections of Indonesian RAs reported in this part. Based on the total occurrence in table 1 , there are 
two moves identified absent in the discussion sections of Indonesian RAs written by the same Indonesian authors namely move I (background information) and move VIII (recommendation). The total of moves occurrences mostly occur in move $\mathrm{V}$ (explanation) at 61 times. The next total of move occurrences is 49 times in move II (statement of results). Meanwhile, the total of moves occurrences in move IV (reference to previous research) and move VII (deduction and hypothesis) is at 34 and 30 times respectively. The total of moves occurrences of move III ((un) expected outcome) and VI (exemplification) are 15 and 17 times. Thus, the total of occurrences of Move I (background information) is 3 times.

Most Indonesian RA discussion sections shows to begin the section by exhibiting move II (statement of results). The statement of result comes up clearer in the discussion section of Indonesian RA in the sentence: "...menghasilkan temuan berupa alasan yang mendasari...”.(“... resulted five fundamental reasons...".) The key word showed the sentence representing the move is "menghasilkan" (resulted) that certainly relates to the reported results in advance.

The next move shows up following move II (statement of results) in the move structure of Indonesian RA discussion sections is move $\mathrm{V}$ (explanation). Move $\mathrm{V}$ is the most frequent appearing in the discussion sections at 61 times. The move contains explanation in the form of reasons based on the reported results. The move is recognized from the excerpt "hal itu dikarenakan tuturan yang..." ("It happened because speech delivered in..."). It is clearly shows that the author offers a reason related to the reported results and it is indicated as causeeffect relationship.

Move IV (reference to previous research) and move VII (deduction and hypothesis occur many times in the Indonesian RA discussion sections. Move IV is recognized similarly to the findings in the English RA discussion sections that nearly all 7 Indonesian authors provide the move in a purpose to support present study. They are not exhibiting it to compare the present study with the previous one.

Move VII (deduction and hypothesis) is identified as opening move in few Indonesian RA discussion sections. The authors operate beginning phrases "dengan demikian" (therefore) and "bisa dikatakan" (it could be said) implied as the emphasis of the reported result. The authors also try to repeat the reported result clearer based on the author's interpretation. In addition, it is the so-called sort of claim about the generalizability of some or all of the reported results.

The rest moves existing in the move structure of Indonesian RA discussion sections are move III ((un) expected outcome and move VI (exemplification). Both moves are at the similar range of occurrences. Move III represents the author-made comment on whether the outcome is expected or not. It is found in the phrases "cukup bagus" (good enough) and "masih mengalami kendala" (faced some obstacles) that obviously show the author's expectation on the reported results.

Move VI (exemplification) is mostly found in the field of Linguistics, especially Pragmatics. The move exhibits examples to support an explanation. It shows that the author operates the keywords "misalnya"(such as), "sebagai contoh" (for example), and "Data" (as seen in Data). Those phrases above are necessary to support previous explanation in the discussion section of Indonesian RA.

Thus, both move I (background information) and move VIII (recommendation) are recognized absent in the Indonesia RA discussion sections. It is similarly found in the English RA discussion sections. It is, then the move structure of Indonesian RA discussion section consisting of 6 moves.

\section{Discussion}

Viewed from 7 authors reported in the findings, most authors operate move II (statement of results) to open and end either in the English and Indonesian RA discussion sections. Move VII (deduction and hypothesis) is mostly seen as an opening sentence in the English RA discussion sections. However, there are few discussion sections identified to open the discussion section with move I (background information) that occurs the least. Thus, the findings imply that nearly all Indonesian authors operated consistent opening moves of their discussion sections of both in English and Indonesian RAs.

The rhetorical patterns of discussion sections of English RAs and those of Indonesian RAs written by Indonesian authors show not too different. The rhetorical patterns of discussion 
sections in English RAs contain 5 frequent moves and the rhetorical patterns of discussion sections in Indonesian RAs contain 6 frequent moves. The findings show that although the rhetorical patterns (moves) of discussion sections of both English and Indonesian RAs above occur almost at the same frequencies, they can be found not only in sequence but also in cycle. Both discussion sections of English and Indonesian RAs can be started with different order moves. There were no moves obligatory found in the discussion sections, what did emerge, was clear cyclical patterning in the writer's choice of moves (Hopkins and Dudley-Evans, 1988; Holmes, 1997; Peacock, 2002). Therefore, Indonesian authors in the findings have and operate sequence moves differently based on their choices and beliefs.

Move I (background Information) has very few occurrences that it is considered to be not occurred in the present study. It seems that Indonesian authors prefer not to repeat information stated in the previous sections. They prefer to express directly statement of what the results were about. The least occurrence of Move I (background information) is not only found in the field of Language, Applied Linguistics, Language Teaching, but also other fields such as Environmental Science, Social sciences, etcetera (Peacock, 2002; Holmes, 1997). Move I, therefore, is not considered as a part of rhetorical patterns of discussion sections of both in English and Indonesian RAs written by Indonesian authors.

Furthermore, the rhetorical patterns of discussion sections of both English and Indonesian RAs in the present study mostly start in cycle of Move II (statement of results), Move $\mathrm{V}$ (explanation), and Move IV (reference to previous research). They also open orderly with Move VII (deduction and hypothesis), Move II (statement of results), and Move V (explanation). These findings can be called as cyclical moves. These cyclical moves are different from the one suggested by Swales (1990), in which he claimed that the most common moves in the discussion sections of English RAs was a cycle of Move I, Move II, and Move IV, while Arsyad (2013) showed the most common moves consisting of Move I, Move II, and Move V. Thus, Move II can be considered as highly preferred move in the discussion sections of RAs.
Move VII (deduction and hypothesis) is also indicated as an opening move of discussion sections in both English and Indonesian RAs. This way of writing organization follows universal writing patterns, the so-called deductive pattern. In the present study, it was found in the field of Applied Linguistics RAs. On the contrary, Atai \& Falah (2010) reported that move VII (generalizability) were not used by Persian Native Speakers who wrote Applied Linguistics RAs. However, Holmes (1997) confirmed that some moves, like Statement of Result, Generalization, and Outlining Subsequent or Parallel Developments are the most prominent. Move VII (deduction \& hypothesis) containing generalization considers prominent, hence it is necessarily needed inside the discussion sections.

The next move following Move II (statement of results) and Move VII (deduction and hypothesis) in the present study is Move $\mathrm{V}$ (explanation). The move is found in the highest frequency, it implies that the Indonesian authors recognize it as a prominent move in writing both English and Indonesian RAs. The idea of the importance of Move $\mathrm{V}$ is also supported by Mirahayuni (2002) that both writer groups had a similar understanding of importance of Move $\mathrm{V}$ in RA writing. Later, it extremely shows that the cycle of Move II or Move VII in the present study reasonably happens and by providing Move $\mathrm{V}$, the RA authors actually show their individual point of views as researchers.

Move IV (reference to previous research) is the next move found following Move $\mathrm{V}$ (explanation). Although the frequency of move IV is in average, Move IV is considered very important. It is similarly showed by Anwar (2010) that Indonesian authors considered Move IV existence important, although this fact is in contrast with what Mirahayuni (2002) stated that in the non-native English RAs, Move IV occurred only in 10 RAs and it shows that the writers may not consider relating their findings with previous findings. Meanwhile, Peacock (2002) proposed that Move 5 (reference to previous research) occurred in $73 \%$ (NS/NNS) and seemed to be important in Language and Linguistics. It is clearly in line with the findings of the present study.

Accordingly, Move III ((un) expected outcome) occurs in both English and Indonesian 
RAs, with the least frequency. Move III mostly occurs to follow Move V (explanation) and move II (statement of results). In the findings, nearly all Indonesian authors provide ((un) expected outcome) with different degree. They tend to soften their expressions in Indonesian RAs. This finding is in line with what Mirahayuni (2002) investigated that Move III had high frequency in both the native and non-native English RAs. She added that analysis of Move III in the native and non-native English RAs raised difficulties due to the relation between functions and choices of lexicogrammatical. On the contrary, Arsyad (2013) and Anwar (2010) reported that Move III was considered absent in Indonesian RAs across disciplines, written by Indonesian authors. Thus, Mirahayuni's ideas seem to confirm the present study that Move III is not frequently chosen by the 7 Indonesian authors.

The last two moves considered to be absent are Move VI (exemplification) and Move VIII (recommendation). In the present study, Move VI occurs only in Indonesian RAs. This is similarly found in Mirahayuni (2002) that Move VI was found in about half of the native and non-native RAs. It is also supported by Arsyad (2013) that Move VI was considered to be absent in the discussion sections. Therefore, it shows that Move VI (exemplification) is greatly used depending on the authors' needs. If they operate Move $\mathrm{V}$ (explanation) providing sufficient information, they, then, will not use Move VI.

Move VIII (recommendation) is considered to be absent in the present study. Move VIII presents the need for further research or suggested possible lines of future research. This is in line with Arsyad (2013) that Move VIII (recommendation) was absent in Indonesian RAs across disciplines, although some researchers still reported that Move VIII was found in average frequency about 40 to $60 \%$ either the native and non-native RAs (Holmes, 1997; Mirahayuni, 2002; Peacock, 2002). Thus, Move VIII is relatively easy to be recognized in the analysis of RAs, but this is not popular move.

To sum up, all Indonesian authors recognize and understand universal patterns of RA writing; especially the pattern of RA writing is proposed by Swales (1990). The different of similar move occurrences and frequency represent their choices, not their ignorance or unknown situation. They freely operate whatever, wherever and whenever moves were. Thus, we have limited situation to interview the authors and crosscheck the journals' editors in order to know how far the editors helped them. This will need to be investigated by next researchers.

\section{CONCLUSION}

Based on the summary of findings and discussion sections, the rhetorical patterns of discussion sections of English and Indonesian RAs written by the same Indonesian authors are not too different. The rhetorical patterns of discussion sections of both in English and Indonesian RAs are different from Swales (1990) model, in terms of move occurrences and move order. Move I (background of Information), Move VI (exemplification), and Move VIII (recommendation) does not commonly occur in the rhetorical patterns of discussion sections of both in English and Indonesian RAs. The selected Indonesian authors tend to straightly open their discussion section with Move II (statement of results) or Move VII (deduction and hypothesis) and report things related to the results in their discussion section with no purpose of making recommendation (Move VIII). Thus, it seems that the authors learn from the common RA format existing in the Indonesian journal publication. The journal is not urged the RA author to provide recommendation as long as the RA has reported results clearly. In other words, the authors are in the position of having their rhetorical patterns suited the context and communities. We realized that there are some limitations found in the present study namely we did not interview our subjects, 7 Indonesians authors and the journals' reviewers/editors in order to crosscheck whether the RAs are originally based on the authors' ideas or the reviewer's suggestions. We therefore, recommend for others researchers to interview the authors and journals' reviewers/ editors in order to know how far the RAs are revised.

\section{ACKNOWLEDGEMENT}

This research was supported by research funds of the Indonesian Directorate General of Higher Education (DIKTI). We would like to thank Professor Bambang Yudi Cahyono, Ph.D. for his guidance and advice during finishing the present study. Thus, we also thank the reviewers of the manuscript. 


\section{REFERENCES}

Al-Qathani, A. K. (2006). A Contrastive Rhetoric Study of Arabic and English research article Introductions. Unpublished Dissertation. Oklahoma State University.

Anwar, K. (2010). Rhetorical Patterns of Research Articles in Language Teaching Journals. Unpublished Dissertation. Pascasarjana, Universitas Negeri Malang.

Arsyad, S. (2013). A Genre-Based Analysis on Discussion Section of Research Articles in Indonesian Written by Indonesian Speakers. International Journal of Linguistics 5(4), 50-70, from http://dx.doi. org/10.5296/ijl.v5i4.3773

Atai, M. R. \& Falah, S. (2010). A Contrastive Genre Analysis of Result and Discussions of Applied Linguistic Research Articles Written by Native and non-Native English Speakers with RespecttoEvaluatedEntities and Ascribed Values. Paper presented at the $10^{\text {th }}$ Pan-Pacific Association of Applied Linguistics Conference in Edinburgh University. Retrieved from http://www. paaljapan.org/resources/proceedings/ PAAL10/pdfs/atai.pdf

Basthomi, Y. (2006). The Rhetoric of Research Article Introductions Written in English by Indonesians. Unpublished Dissertation. Pascasarjana, Universitas Negeri Malang.

Chakorn, O. (2002). Contrastive rhetoric of English persuasive correspondence in the Thai business context: crosscultural sales promotion, request and invitation. Unpublished $\mathrm{PhD}$ thesis. University of Warwick.

Connor, U. (1996). Contrastive rhetoric: Crosscultural aspects of second language writing. Cambridge:Cambridge University Press.

Connor, U. (2002). New Directions in Contrastive Rhetoric. TESOL QUARTERLY, 36 (4), 493-510, from https://doi. org/10.2307/3588238.
Holmes, R. (1997). Genre Analysis and the Social Sciences: An Investigation of the Structure of Research Article Discussion Sections in Three Disciplines. English for Specific Purposes, 16(4), 321-337, from https://doi.org/10.1016/S08894906(96)00038-5.

Hopkins, A \& Dudley-Evans, T. (1988). A GenreBased Investigation of the Discussion Sections in Articles and Dissertations. English for Specific Purposes, 7(2), 113121, from https://doi.org/10.1016/08894906(88)90029-4.

Kaplan, R. B. (1966). Cultural Thought Patterns in Intercultural Education. Language Learning, 16(1), 1-20, from https://doi. org/10.1111/j.1467-1770.1966.tb00804.x.

Kuntjara, E. (2004). Cultural Transfer in EFL Writing: A Look at Contrastive Rhetoric on English and Indonesian. K@ta Journal, 6(1), 13-29, from https://doi.org/10.9744/ kata.6.1.13-29

Mirahayuni, N. K. (2002). Investigating Generic Structure of English Research Articles: Writing Strategy Differences between English and Indonesian Writers. TEFLIN Journal, 13(1), 22-57, from http://dx.doi. org/10.15639/teflinjournal.v13i1/22-57.

Ozmen, K.S. (2016 Rhetorical Analysis of the Doctoral Abstracts on English Language Teaching inTurkey. i-manager's Journal Teaching on English, 6(1), 25-35, from https://doi.org/10.26634/jelt.6.1.4808.

Peacock, M.(2002). Communicative Moves in the Discussion Section of Research Articles. System, 30(4), 479-497, from https://doi. org/10.1016/S0346-251X(02)00050-7.

Safnil. (2013). A Genre-Based Analysis on the Introductions of Research Articles Written by Indonesian Academics. TEFLIN Journal, 24(2), 180-200, from http://dx.doi.org/10.15639/teflinjournal. v24i2/180-200. 
Susilo. (1999). Rhetorical Patterns as Reflected in Argumentative Discourse in the Jakarta Post. Unpublished Thesis. Pascasarjana, Universitas Negeri Malang.

Susilo. (2004). Thought Patterns Reflected in the Linguistic Features in Indonesian and English Letters Written by Indonesian. Unpublished Dissertation. Pascasarjana, Universitas Negeri Malang.
Swales, J.M. (1990). Genre Analysis: English in Academic and Research Settings. Cambridge: Cambridge University Press.

Tseng, F. P. (2011). Analysis of Move Structure and Verb Tense of Research Article Abstracts in Applied Linguistics Journals. International Journal of English Linguistics, 1(2), 27-39. Doi: 10.5539/ ijel.v1n2p27. 